\title{
MNEs, human rights and the SDGs - the moderating role of business and human rights governance
}

\section{Stefan Zagelmeyer and Rudolf R. Sinkovics*}

The Millennium Development Goals (MDGs) and the Sustainable Development Goals (SDGs) ascribe specific roles to business organisations and have thus invigorated discussions on the link between the activities of multinational enterprises (MNEs) and international development. In the development of the MDGs and the SDGs, the human rights-related capabilities approach to development has featured prominently. Yet, so far, international business research on the links between MNEs and sustainable management has largely overlooked the human rights aspect. This paper integrates human rights into the debate on the role of business activities in sustainable development. Drawing on the business and human rights $(\mathrm{BHR})$ governance approach, which analyses the governance mechanisms and structures that govern the relationships between human rights duty-bearers and rights-holders in the business and human rights field, the paper argues that BHR governance can act as moderator in the design, implementation and evaluation of business policies and practices seeking to contribute to the advancement of the SDGs. It shows how BHR governance may support, positively influence and reinforce the impact of private sector activities on international sustainable development.

Keywords: business and human rights governance, international business, Millennium Development Goals, multinational enterprises, Sustainable Development Goals, UNGPs, UN Guiding Principles on Business and Human Rights

Stefan Zagelmeyer is Reader in Comparative and International Business at The University of Manchester, Alliance Manchester Business School, United Kingdom. Rudolf R. Sinkovics is Professor of International Business at the University of Auckland, Graduate School of Management, New Zealand, and Visiting Professor at Lappeenranta University of Technology, Finland. The corresponding author is Stefan Zagelmeyer (stefan.zagelmeyer@manchester.ac.uk). 


\section{Introduction}

Since the publication of the Brundtland Report in 1987 (World Commission On Environment and Development, 1987), there has been an increasing interest in the link between international business activities and sustainable development (Hart, 1997; Meyer, 2004). Although international business (IB) as an academic field has traditionally focused on the impact of multinational enterprises (MNEs) and different types of foreign direct investment (FDI) on economic development, usually centred around economic growth, recent research has gradually shifted towards broader approaches to development and the use of additional social indicators. Recent contributions analyse the impact of MNEs on inequality (Giuliani, 2018) and poverty (Kolk, Rivera-Santos and Rufín, 2018), and discuss the role of MNEs in sustainable development (Kolk and van Tulder, 2010; van Tulder, 2018; van Tulder, Verbeke and Strange, 2014; Williams, 2014).

Since the introduction of the United Nations Millennium Declaration and the associated Millennium Development Goals (MDGs) and subsequent Sustainable Development Goals (SDGs), the issue of sustainability has taken centre stage in international development policy, as well as for international business (Organisation for Economic Co-operation and Development [OECD], 2016; van Zanten and van Tulder, 2018). A 2017 special issue of this journal provides an overview of the role of MNEs in the achievement of the SDGs (Witte and Dilyard, 2017), and a review of work on the link between MNEs and the impact of IB on the four sustainable development dimensions: people, planet, peace and prosperity (the 4P approach) (Kolk, Kourula and Pisano, 2017). In related work, Bush, Oosterveer, Bailey and Mol (2015) discuss the role of business in sustainability governance.

Despite agreement on the relevance of sustainable development, there have been debates about the definition of sustainability and its theoretical grounding (Banon Gomis, Guillen Parra, Hoffman and McNulty, 2011; Monkelbaan, 2018). In the development of the MDGs and the SDGs, the human rights-related capabilities approach to development (Sen, 2003, 2005) has featured prominently. However, so far, IB research on the links between MNEs and sustainable development has, to a large extent, ignored human rights, and especially the potential relevance of the 2011 United Nations Guiding Principles on Business and Human Rights (UNGPs).

This paper integrates human rights into the policy debate about the role of business activities in sustainable development. Drawing on the business and human rights (BHR) governance framework suggested by Zagelmeyer (2020), which analyses the governance mechanisms and structures that govern the relationships between human rights duty-bearers and rights-holders in the business and human rights field, the paper argues that BHR governance - as an institutional form of sustainability governance - can provide reference points and analytical tools and thus act as 
moderator in the design, implementation and evaluation of international business policies and practices seeking to contribute to the achievement of the SDGs.

In section 2, the paper sets the scene for the subsequent analysis by introducing and analysing the link between MNEs, human rights and sustainable development. This part includes a discussion of the role of business in sustainable development policy initiatives, focusing on the debate about the MDGs and the SDGs. It furthermore analyses the role of human rights in development policy, highlighting the importance of the capabilities approach of Sen (2004), before moving on to discuss the human rights aspect in the transition process from the MDGs to the SDGs. Section 3 discusses the potential role of BHR governance in sustainable development. This part of the paper commences with a critical discussion of the role of business in MDGs/SDGs-related international development policy from a human rights perspective and looks at design principles, implementation, and evaluation. It then discusses how the UNGPs can be used to address the shortcomings identified and concludes by proposing the BHR governance approach. Section 4 discusses how the BHR governance approach can moderate the link between MNE activities and the achievement of the SDGs. Section 5 summarises the findings, discusses the policy relevance of the proposed approach and sets out areas for future research.

\section{The role of MNEs and human rights in sustainable development}

\subsection{International business and sustainable development}

The role of business in international development has been widely discussed, ranging from philanthropic approaches to critiques of neo-imperialism to neoliberal approaches (Harriss, 2014; Moran and Stone, 2016). IB has traditionally focused on the role of FDI and MNEs in development (Dunning, 1981; Dunning and Narula, 1996). References to the role of business can be found in early publications on sustainability (Carley and Christie, 1992), management literature (Hart, 1997), and policy papers (Commission of the European Communities, 2002).

While these vigorous discussions have made a valuable contribution, central elements to the debate, such as the practical relevance and impact of international business activities related to cross-border trade, global value chains and foreign direct investment warrant further exploration. Traditionally, most IB activities have been orchestrated through MNEs based in developed economies with relatively mature institutions in terms of the rule of law, competition policy, and human rights, including labour governance. Yet, MNEs often operate in economies where institutions governing international business have been described as less mature, 
sophisticated and effective in enabling and supporting market activity, and thus sometimes labelled as "institutional voids" (Doh, Rodrigues, Saka-Helmhout and Makhija, 2017; Khanna and Palepu, 1997). One particular concern is that the positive outcomes of IB activities accrue to MNEs, their owners and supporting local agents, but fail to filter through to local communities in the form of economic and social development. Another concern is that MNEs crowd out local business organisations, thereby increasing developing countries' dependence on foreign direct investment.

International development policy and the debate on sustainable development entered a new stage when the Millennium Declaration, adopted by the UN General Assembly in 2000 (UN, 2000), set out a strategic vision for the twenty-first century and integrated different development initiatives into one framework. One hundred ninety-one UN member states committed themselves to work towards the achievement of eight goals, accompanied by 80 targets and 48 indicators, until 2015. The Millennium Development Goals aimed at supporting human capabilities and development by emphasising human capital, infrastructure and human rights. In 2015 the UN General Assembly adopted Agenda 2030 (UN, 2015b), which encompasses 17 goals and 169 targets. The entire set of goals, targets and measurement indicators is commonly known as the Sustainable Development Goals. They provide orientation for global development efforts for the period 2016 to 2030 (UN, 2015b, 2015a) and build on the MDGs (Pogge and Sengupta, 2016). The MDGs and SDGs represent a significant departure from previous initiatives to assist human and social development, by focusing on, and prioritising, a select number of objectives, emphasising measurement and accountability, setting specific deadlines, and providing an institutional framework for promotion (Alston, 2005). In contrast to the MDGs, the SDGs agenda is more comprehensive, emphasising the environmental dimension, and more universal in focus, addressing all countries' sustainability needs instead of focusing only on developing countries.

The link between MNEs and Agenda 2030 can be discussed at several levels. At the organisational level, SDG target 12.6 encourages the adoption of sustainable practices and engagement in sustainability reporting for companies. SDGs 8 and 9 emphasise the role of small and medium-sized companies in providing both economic growth and decent work. The SDG Compass (GRI [Global Reporting Initiative], UNGC [UN Global Compact] and WBCSD [World Business Council for Sustainable Development], 2015) provides a detailed guide of indicators and tools to assist companies' contribution to the achievement of the SDGs, emphasising the business case related to future business opportunities, the enhanced financial value of corporate sustainability and improved stakeholder relations.

While the OECD (2018b) also emphasises the business opportunities and market potential for goods and services offered by sustainable business, it refers more generally to the macro level by highlighting the potential of the private sector for 
contributing "scale and powerful effective transformation" and its "expertise and capacity for innovation" to the implementation and achievement of the SDGs. The MDGs emphasise the role of partnership between the public sector, the private sector and civil society in the pursuit of development (UN, 2000). The SDGs aim at "bringing together governments, the private sector, civil society, the United Nations system and other actors" to mobilise "all available resources" (UN, 2015b), explicitly mentioning micro-enterprises, cooperatives and multinationals "as drivers of productivity, inclusive economic growth and job creation” (UN, 2015b).

Both the MDGs and the SDGs haveled business organisations and non-governmental organisations to discuss and address the link between business and sustainability. A joint statement from the Global Agenda Councils of the World Economic Forum endorses the idea of business contributing to sustainable development by, among other things, "offering an image of business sustainability that can begin to inform business decisions and the creation of new business models" (World Economic Forum). Furthermore, there have been various initiatives that relate to the views of business and its stakeholders on sustainability that identify good practice and issue recommendations for business to contribute to the achievement of the sustainability goals (GRI et al., 2015; Oxfam, 2017, 2018; Shift and WBCSD, 2018).

\subsection{Business, development policy and human rights}

Reflecting on the debate about the role of business in development, Shift (2016) notes that human rights had been ignored for a long time. This position is mirrored by the relatively marginal role human rights played in the international development literature up and into the 1990s (Sano, 2000), and in the IB literature (Wettstein, Giuliani, Santangelo and Stahl, 2019). Alston (2005) claims that the human rights debate and the development debate have largely developed in parallel, with few points of contact. Figure 1 provides an overview of the most important international initiatives with respect to (i) the sustainable development debate; and (ii) the BHR debate. More recently, Gready and Ensor (2016) identified trends of convergence between the two debates.

The late 1990s/early 2000s saw the emergence of Sen's human capabilities approach to international development (Sen, 2003, 2004, 2005), which explicitely links development to human rights. Going beyond the utilitarian approaches traditionally used in economics, Sen's approach provides for a pragmatic orientation by highlighting a critical distinction between, on the one hand, human rights as ethical articulations (i.e. expressions in a debate on ethical norms), and, on the other hand, as agreed norms that constitute rights and obligations for different social actors. While the former highlights philosophical considerations, the latter takes a political and legal perspective that can be expanded to include political processes of negotiation and agreement on an implicit or explicit social contract on human rights. 
The capabilities approach of Sen (2004) emphasises the role of individual freedom, which replaces utility as the basis for the ethical evaluation of human rights, distinguishing between two aspects of freedom. Substantive opportunities and freedom of processes refer to procedural (e.g. process equity or due process) and substantive (e.g. having the means to achieve valuable combinations of human functioning) issues related to human rights. In relation to valuable combinations of human functioning (what a person is able to do or be), Sen introduces the concept of capability "as a kind of freedom [that] refers to the extent to which the person is able to choose particular combinations of functioning [...], no matter what the person actually decides to choose." Sen moves the human rights debate towards a normative discussion, placing the capability approach in the context of a theory of knowledge about collective choice that has to consider "the fairness of processes involved and [...] the equity and efficiency of the substantive opportunities that people can enjoy".

Referring to the discussion about the MDGs, Alston (2005) identifies several challenges for a human rights-based approach to development. The first relates to the challenge that human rights-related goals are often stated in abstract and general ways, which makes it difficult to provide concrete guidance to actors in the human rights field and to measure and monitor human rights-related developments. Second, human rights-related policy prescriptions, such as "the corresponding human rights obligations of duty bearers" (Alston, 2005) often state a general problem or dilemma and do not provide guidance for resolving the issue. In this respect Alston also highlights that guidance may be helpful at the micro level, but less so at the macro level. Third, with respect to the involvement of private businesses and partnership between the private and public sectors, policy statements often use buzzwords such as "strategic partnerships" without necessarily outlining the goals, processes and content involved in such partnerships.

Taking a political economy perspective, Schmidt-Traub (2009) and Langford, Malcolm, Sumner, Andy, Yamin and Alicia (2013) attribute the failure of many countries to achieve the MDGs to a multiplicity of reasons, including inadequate governance, failure to respect essential civil and political rights and geographical and demographic factors. Particularly noteworthy is the argument that in the absence of effective governance structures or respect for civil and political rights, national elites lack the will to pursue long-term development goals, enforce the rule of law and realise human rights, and thus are not able to effectively pursue and achieve goals such as the MDGs. In such situations, a human rights-based approach could strengthen development initiatives by emphasising the role of transparency and the accountability of decision-makers, which is ultimately needed to achieve development outcomes. 


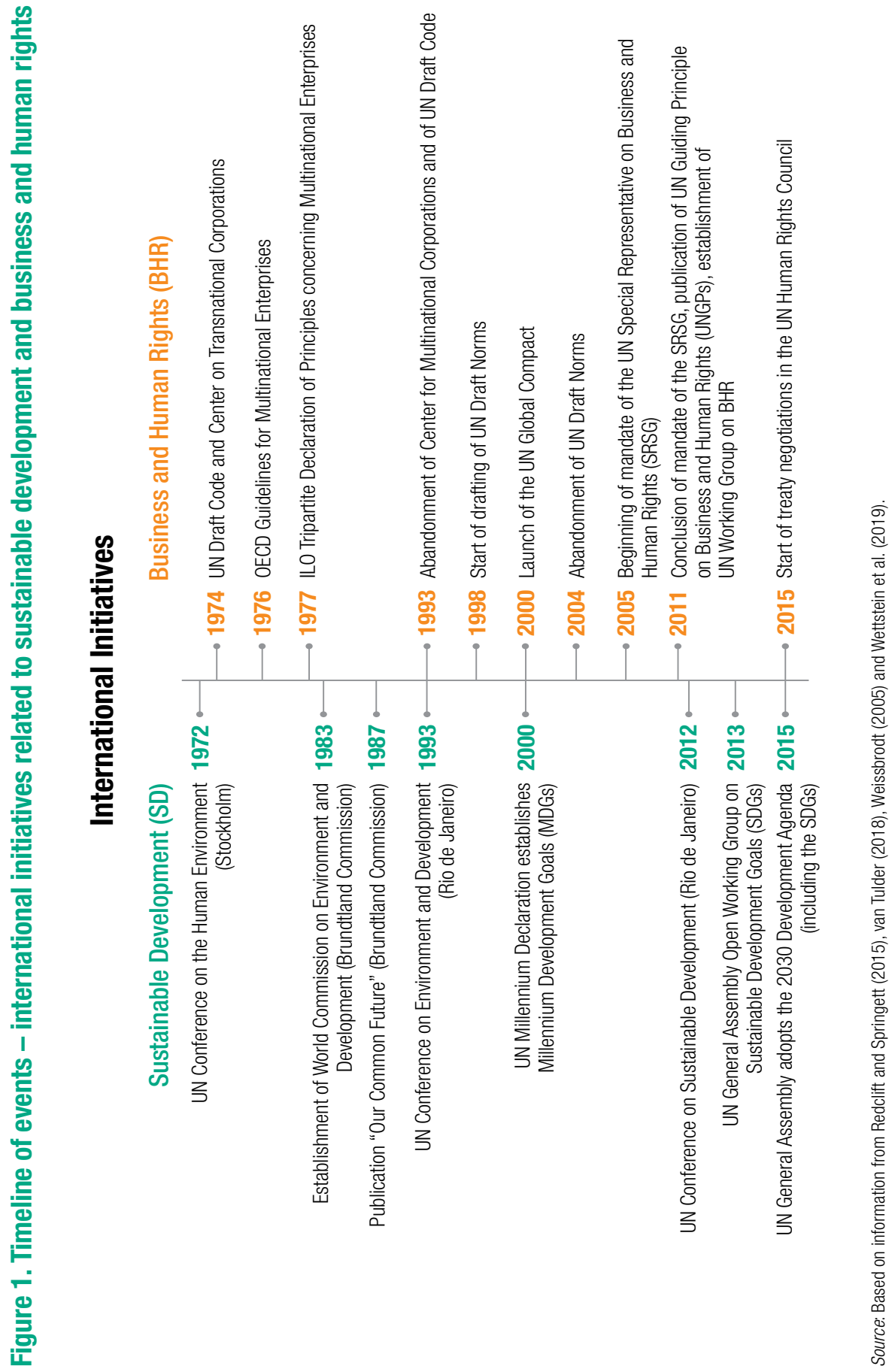




\subsection{From the MDGs to the SDGs}

The Millennium Declaration placed human rights at the centre of international development (Mclnerney-Lankford and Sano, 2010; United Nations Development Programme, 2013). Although development policy traditionally was not organised around the human rights approach to development, the Millennium Declaration (UN, 2000) explicitly suggests implementing the MDGs in a human rights-sensitive manner, and using human rights instruments to promote their achievement (Kuruvilla, Singh, Bustreo, Friedman, Hunt and Luchesi, 2012; Office of the United Nations High Commissioner for Human Rights [OHCHR], 2008, 2010). The business sector has taken up these suggestions and implemented projects in a rights-aware fashion (Business Leaders Initiative on Human Rights [BLIHR], 2010).

Nevertheless, the MDGs were also criticised from the human rights perspective, with respect to their technocratic nature, quantitative focus, selection of a limited number of goals, lack of a full human rights framework including civil and political rights, their focus on the state and neglect of the private sector, and an inadequate system of monitoring (Alston, 2005; Fukuda-Parr and Greenstein, 2013). SchmidtTraub (2009) argued that while the MDGs were consistent and compatible with a human rights-based approach, the focus was on normative questions and aspects, rather than on operational aspects that could inform day-to-day decisions of practitioner governments. Furthermore, Alston claimed that the MDGs potentially distracted governments and donors from human rights issues and that they competed with existing initiatives.

As the SDGs are widely considered an expansion of the MDGs (Figure 2), one may be inclined to assume that the role of human rights has become even more prominent. In fact, the 2030 Agenda was designed with an explicit commitment to human rights, as indicated in the preamble; several references to international human rights treaties and instruments; and the explicit aim to "seek to realise the human rights of all" (UN, 2015b). An analysis by the Danish Institute for Human Rights shows that of the 169 SDGs targets, 156 are linked to international human rights and labour standards (The Danish Institute for Human Rights, 2019).

However, there are several critical views of the role of human rights in the SDGs and Agenda 2030. To start with, while a human rights approach would require the complete end of the non-realisation of human rights, the SDGs - in line with the mainstream development policy discourse - take an incremental approach, thus generating "a false sense of success" and allowing "governments to go slow on the realisation of human rights" (Pogge and Sengupta, 2016). This is particularly relevant for shifting the respective discourses and shaping the narratives of governments with a poor or suspect track record on human rights. 


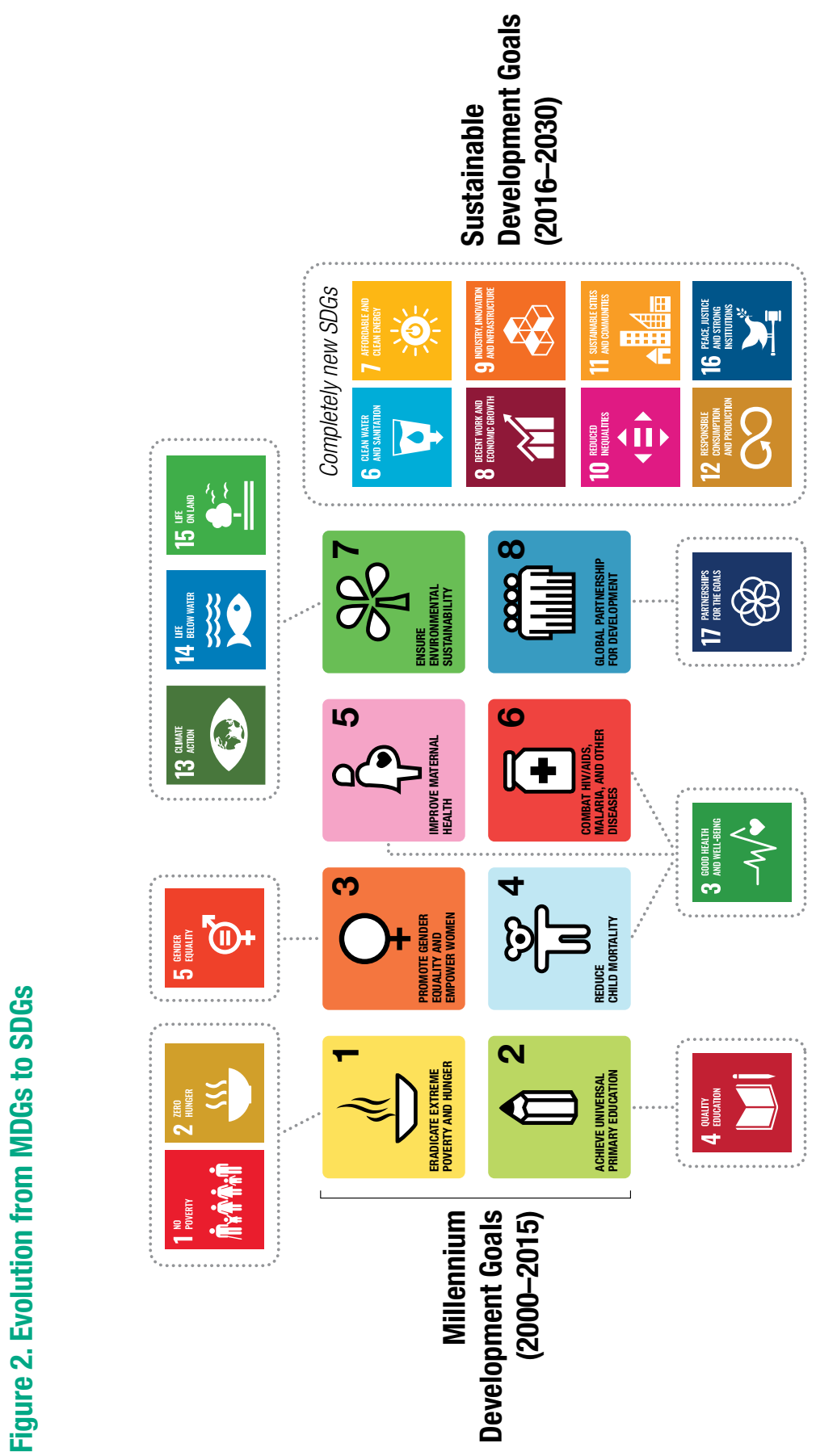


Concerning the content and process, the large number of SDGs - which Langford (2016) attributes to the highly participative drafting process - very much present a menu that allows actors to hand-pick particular goals while neglecting others. As any improvement of the human condition is appreciated, businesses may be tempted to work towards those goals for which they can identify a business case, those that have the highest impact on reputation, or those for which a cost-benefit analysis yields the most favourable ratio, instead of taking a universal approach to human rights.

The SDGs do not specify a clear division of labour, attribution of responsibility or instruments to ensure accountability among agents operating in the field. This has negative implications for transparency, coordination and accountability. Working towards particular goals is an emergent process in which the agents can pick and choose goals and policies as they like, considering what is "nationally appropriate" (UN, 2015b). Powerful agents such as affluent states, international organisations and multinational enterprises are "shielded from concrete responsibilities for achieving the SDGs" (Pogge and Sengupta, 2016). Dealing with an increased number of goals, targets and indicators may draw resources and attention away from either the overall goal of improving the human condition, or distract from fundamental human rights challenges. Both may lead to human rights being treated in a token fashion.

Wagner (2017) argues that the SDGs emphasise economic, social and cultural rights. While this may be adequate for a general development policy approach under which consensus among the involved states may be more easily achieved, it runs the risk of ignoring second-generation political and civil rights. Access to social and economic wealth is very much influenced by national and international social and economic policies and practices, which in turn are heavily influenced by interest groups, such as industry associations, corporations, unions and NGOs that lobby for favourable terms for themselves and their constituencies. A challenge to addressing inequalities is related to the problem of legitimate decision-making and representing the marginalised parts of the population, who are largely deserving but lack access to representation in political and economic decision-making.

\section{The role of business and human rights governance in sustainable development}

Being influenced by human rights-oriented development thinking, both the UN MDGs and the SDGs envision specific and supportive roles for (private) business and private-public partnerships in international development. Yet, both the MDGs and the SDGs seem to have largely ignored the parallel UN-level debates on the link between transnational business and human rights, an issue first covered by the 
preparation and failure of the Draft Norms on the Responsibilities of Transnational Corporations and other Business Enterprises with Regard to Human Rights in 2004 (UN Commission on Human Rights, 2003; Weissbrodt, 2005), which then led to the development and 2011 endorsement of the UN Guiding Principles (UNGPs) (Backer, 2012; OHCHR, 2011). By establishing a specific number of principles, the UNGPs created the nucleus for an international business and human rights governance system (Ruggie, 2014).

This section explores the role that international BHR governance, originating in the UNGPs, can play in moderating the link between international business and sustainable development. To this end, we will first discuss criticism levelled at how business and the private sector are treated in the international development policy debate about the MDGs and the SDGs, from a human rights perspective. We will then discuss the potential contribution of the UNGPs and suggest different ways in which international $\mathrm{BHR}$ governance can address these shortcomings.

\subsection{A human rights view on the role of business in the sustainable development debate}

There are several criticisms of the role ascribed to business in MDGs/SDGs-related international development policy from the human rights perspective. These criticisms fall into three categories: design principles, implementation, and evaluation.

\subsubsection{Design}

One of the design principles of the SDGs is voluntarism, which provides business with a choice of the activities they wish to pursue to support sustainable development. The advantages and disadvantages of this approach have been extensively discussed in the business ethics/human rights debate on voluntary versus mandatory compliance, which focuses on persuading business to pursue or abandon certain behaviours (Mares, 2015; Wettstein and Waddock, 2005). As voluntarism sets a low threshold for companies to engage in any type of socially responsible behaviour, it does not necessarily ensure that all activities of business organisations are socially responsible. As described above, it allows companies to cherry-pick sustainability goals that suit them, while perhaps disregarding human rights that relate to other goals. This creates tensions with respect to priorities and the universal character of human rights as defined by the International Bill of Human Rights.

There are claims that development policy based on voluntarism with regard to business actors encourages philanthropy as the paradigmatic fundamental of corporate social responsibility (CSR) (e.g. Shift (2016). Among other things, the philanthropy-related approach focuses on the outcomes of business activities 
instead of corporate responsibility in the process of generating profit through business activities at a more fundamental and systemic level, supporting changes in the business model (micro level) or the institutional setting of the business and the economic system (macro level).

While the SDGs emphasise the role of business and private-public partnerships in sustainable development, there is no clear attribution of roles and responsibilities to different actors, for example, the distinction between duty-bearers, rights-holders and other actors is not defined (Pogge and Sengupta, 2016). Relatedly, there seems to be no clear focus on either accountability in general, or specific instruments through which actors can be held accountable. The underlying assumption appears to be that every activity supporting the achievement of the SDGs operates in the context of a positive-sum game, thus potentially ignoring conflicts between goals and conflicts of interest between duty-bearers and rights-holders. Consistent with the neglect of conflicts is the lack of stipulations regarding conflict resolution, e.g. grievance or dispute resolution mechanisms.

\subsubsection{Implementation}

While all the issues raised in the previous sub-section have an impact on the processes of choosing and implementing policies to support the achievement of the SDGs, Shift (2016) draws our attention to the cognitive framing of human rightsrelated policies and practices by claiming that the mainstream of the BHR debate emphasises compliance, i.e. businesses avoiding negative impacts or harm with respect to human rights.

A different perspective from which to look at the positive impacts of the realisation of human rights is frequently taken by the advocates of CSR, social investment and strategic philanthropy approaches, emphasising the positive societal effects of realising human rights. More recently, the CSR and responsible business debate has shifted towards shared value creation (Porter and Kramer, 2006), social value creation (Sinkovics, Sinkovics, Hoque and Czaban, 2015) or shared responsibility (Posner, 2015).

Moving to more specific aspects of the human rights debate, Shift argues that there are significant differences between the discourses about business implications for people and the environment. Whereas environmental discourse focuses on reducing the negative environmental impact of business activities, social discourse focuses on positive impacts generated by a mix of philanthropy, social investment and socially responsible business models. In contrast, the discussion of business and human rights concentrates on reducing the negative impact of business activities on people, while the residual discourse with respect to the environment considers additional opportunities. 
Without ignoring the necessity of compliance with respect to human rights regulations, positive framing processes can alter the way in which corporate decision-makers perceive human rights-related policies and practices, and could shift the emphasis within corporations from a more passive, compliance-oriented approach to a more proactive, engagement-oriented approach to support the achievement of the SDGs.

\subsubsection{Evaluation}

The large number of SDGs and the contested nature of operationalising the respective goals and establishing valid and reliable measurement indicators create another layer of complexity for the achievement of the SDGs. Lack of clarity and guidance in this respect may exacerbate challenges identified with respect to the design characteristics and principles of the SDGs (Pogge and Sengupta, 2016). Among other things, this may add additional degrees of freedom and discretion to business in terms of assessing and reporting its contributions to the achievement of the SDGs, while at the same time generating issues with respect to transparency and accountability.

The idea of separating positive and negative human rights impacts has intriguing implications, as suggested by Shift (2016), with respect to thinking about measurement issues and designing assessment and control. At a general level, for each of the goals, a human rights-based approach to measurement would require the creation of two separate independent variables: one for the negative impact (related to compliance and the avoidance of negative impact on human rights) and one for the positive impact (emphasising the contribution of the realisation of human rights for the achievement of sustainable development).

The 17 goals and 169 targets included in the SDGs, with each of the goals potentially related to a different set of human rights, generate a high degree of complexity for the assessment of business policies from a human rights perspective. Assuming human rights are universal, should the assessment of goals and human rights be based on separate indicators, or can goals and/or human rights be aggregated into a single indicator? Should each of the goals and/or human right have the same weight in the aggregation process? As far as the assessment of corporate behaviour is concerned, one implication would be to check whether and to what degree rights have been abused for each separate aspect of human rights. Compliance would only be achieved if there is no abuse at all. The positive impact would be analysed and measured separately. 


\subsection{Business and sustainable development: the potential role of the UNGPs}

Taking a human rights perspective, the previous section highlighted several issues with respect to the role of business in the 2030 Agenda in terms of design, implementation and evaluation. We next discuss the extent to which the UNGPS can address the shortcomings identified.

Building on the International Bill of Human Rights, the 2011 UNGPs lay the foundations for an emerging multilevel and polycentric business and human rights governance system by establishing a set of global standards that covers all companies in all UN member states (Ruggie, 2013). The UNGPs have been integrated into the OECD Guidelines for Multinational Enterprises (OECD, 2011, 2018a) and the International Labour Organization Tripartite Declaration of Principles concerning Multinational Enterprises and Social Policy (ILO, 2017). While the UNGPs can be interpreted in a rather simple and passive "not engaging in harmful activities" fashion, their function and potential impact are more complex. In fact, the principles, stipulations and recommendations included in the UNGPs can be used to help clarify issues, address shortcomings, provide practical guidelines and ultimately moderate the role of business in sustainable development.

\subsubsection{Design}

The design of the SDGs with respect to the role of business involves an inherent tension between voluntarism and compliance. The UNGPs apply universally and unequivocally to all business organisations - be they transnational or domestic, public or private, operating in the formal or the informal sector - and all human rights. They do not offer a menu with options for business organisations to sign up to or disregard.

The UNGPs involve an expectation of "how business organisations make their profits, not how they spend them" (Shift, 2016). Companies are expected to respect the international bill of human rights at all stages of the value creation process. This contrasts with a focus on philanthropic activities that occur after the value creation process has been completed, focusing on distributing the outcomes of successful business to contribute to sustainable development.

The UNGPs define the roles, responsibilities and rights of different actors in the business and human rights field. They confirm the role of the state as primary duty-bearer to protect human rights and its responsibility to prevent, investigate, punish and redress human rights abuses by companies. The UNGPs also include the expectation that companies explicitly commit to human rights, by publicly making such a commitment, by conducting human rights due diligence, and by establishing policies to remedy any adverse human rights impacts of their business 
activities. In addition, they require the state and companies to establish governance structures that provide victims of human rights abuses with access to effective remedy through grievance mechanisms (OHCHR, 2011, 2012, 2014). Thus, the UNGPs specify the rights and obligations of the human rights rights-holders and duty-bearers, and include a clear division of labour and responsibilities with respect to the role of governments and states, as well as of business organisations.

\subsubsection{Implementation}

The UNGPs can support businesses in the achievement of the SDGs in various ways. They involve a set of global standards that orient companies and other actors involved in, and affected by, international business activities as to how to address human rights issues linked to business activities.

With respect to framing, the UNGPs allow for both negative framing in terms of compliance with international human rights standards, but also positive framing by encouraging companies to not only contribute to the realisation of human rights by avoiding abuse and violations, but also to support the development of human capabilities. For duty-bearers this ensures a floor of minimum terms and conditions for their business activities. In the discussion on the SDGs, the UNGPs provide a foundation upon which additional, innovative responsible business behaviour can build. If effectively implemented, this floor would take human rights (abuses) out of competition in the respective factor and product markets. Consequently, businesses would no longer be able to compete by undercutting terms and conditions related to human rights standards, regardless of whether these are in the environmental, labour or consumer protection spheres.

At this stage it is important to address a controversial aspect of the human rights discussion related to the definition, specification and operationalisation of human rights standards. We need to distinguish between two aspects of human rights. On the one hand, human rights can be understood as universal minimum standards that may not be abused. This relates to the earlier discussion of negative framing and points towards human rights compliance. On the other hand, beyond this safety net, we may consider higher levels of human rights realisation in relation to the maximisation of human capabilities, with its positive association with sustainable development, linked to positive framing and Sen's capabilities approach.

This distinction allows different elements and interventions in human rights discourses. In this regard, Shift (2016) distinguishes between (i) primary discourses that are about ending human rights abuses; and (ii) additional discourses highlighting opportunities for socially responsible behaviour beyond the human rights minimum standards. Accordingly, one may think about measuring these dimensions separately in order to avoid conflation. 


\subsubsection{Evaluation}

Turning to the issue of evaluation, the implementation of the UNGPs could be analysed with respect to both compliance and supporting capability development. Universal corporate compliance with international minimum human rights standards would remove human rights as a potential pawn in competition between dutyholders and establish a safety net for rights-bearers. Furthermore, with companies going beyond the minimum compliance requirements, the application of the UNGPS implies a positive change in the situation of rights-holders in terms of freedom and unleashing human capabilities for future sustainable development. Using the UNGPs also represents a move away from specific target dates through focusing on long-term sustainability. It would also avoid negative motivational effects if the goals turn out to be unrealistic. Thus, the UNGPs include obligations that can further strengthen actors' long-term commitment.

As far as the evaluation of corporate human rights policies and practices is concerned, the UNGPs do not include any specific stipulations beyond generally requiring companies to engage in human rights risk assessment and due diligence, providing guidelines with which to assess complicity in human rights abuses, and suggesting specific effectiveness criteria for the evaluation of non-traditional grievance mechanisms, such as legitimacy, accessibility, predictability, equity, transparency, rights compatibility and dialogue orientation, as well as acting as a source of continuous learning (OHCHR, 2011). These criteria provide useful starting points for discussion of the design of an evaluation system.

\subsection{Building on the UNGPs: the business and human rights governance framework}

The UNGPs establish the nucleus for an international BHR governance system that can be used to support the role of MNEs in sustainable development, specifying and defining the roles of states and business, and establishing reference points in terms of expected behaviour. Building on the UNGPs, the BHR governance approach - an adaptation and extension of Budd's (2004) efficiency, equity and voice approach - is designed around the idea of business and human rights being a field that includes actors, actor interests, and relationships between different actors (Zagelmeyer, 2020). Actors can be both individual agents (e.g. workers or managers) and collective agents (e.g. unions, employer organisations or other nongovernmental agents). Agents are engaged in bilateral or multilateral relationships, for example between employer and employee or between seller and buyer, in which they are rights-holders and/or human rights duty-bearers. From the perspective of the actors, particular relationships are purposeful and serve particular objectives, i.e. achieving profits, or earning a living. 
Each individual and collective actor has their own specific set of interests and related objectives, which influences their choice of strategy and motivates them to engage in goal-directed behaviour and activities. Assuming potentially overlapping, competing and conflicting interests between the different actors, each dyadic relationship between duty-bearer and rights-holder can be interpreted as a bargaining problem that raises questions about the relative distribution of power between these actors and the rules governing their interactions, i.e. governance (Budd, 2004). Thus, society needs to find a way to achieve a workable balance of objectives. This balance needs to equally apply at the micro level of the dyadic relationships as well as at the societal macro level. With respect to the latter, Budd's efficiency, equity and voice approach can be reinterpreted to address broader societal objectives of wealth, justice and democracy. Assuming human rights are universal, the potential tensions between the realisation of different human rights (e.g. property rights and labour rights) show the need to balance the three objectives.

Governance can be defined as "an institutional framework in which the integrity of a transaction or related set of transactions is decided", aiming "to effect good order" (Williamson, 1996). Governance structures involve decision-making procedures for regulating and governing relationships between actors. According to whether, or not, state or state agencies are involved in governance, we can distinguish between public and private governance.

The need to balance the objectives of efficiency, equity and voice can be supported by a BHR governance system that includes a specific configuration of governance structures, which provide the formal and informal institutional rules for the relationships between the different actors. Within such a governance system, a relationship between two or more actors may be regulated by a multiplicity of governance mechanisms and structures at different levels, e.g. individual, company, national, or international level. Governance modes may include, for example, environmental legislation, international labour standards, or multi-stakeholder agreements. A BHR governance system thus consists of a specific arrangement of governance mechanisms and structures within a defined entity, such as an industry, a firm, a country or a value chain, in which each relationship can be regulated by different configurations of governance mechanisms and structures. "Good" governance of the respective relationship requires that the different objectives are balanced. 


\section{MNEs and sustainable development: the moderating role of human rights governance}

\subsection{BHR governance and the link between MNEs and sustainable development}

The BHR governance approach can be used to analyse the human rights implications of IB activities, such as trade, FDI, different modes of MNE foreign market entry or operation, or specific organisational configurations, such as global value chains (Gereffi, 2014; Gereffi, Humphrey and Sturgeon, 2005) or the global factory (Buckley and Strange, 2015). The UNGPs and the BHR governance approach taken together can support business in contributing to the achievement of the SDGs in a complementary way. The UNGPs define the roles and responsibilities of states and business organisations, provide orientation with respect to the activities of business and the relationship between duty-bearers and rights-holders, and include provisions for access to remedy and the design and evaluation of grievance mechanisms.

Whereas the UNGPs deal with design aspects, such as the assumptions, principles, and values involved, and provide ways of framing human rights issues, the BHR governance approach provides us with a toolbox for describing, analysing and evaluating actors, relationships and the institutions that govern the relationships between human rights duty-bearers and rights-holders. In addition to institutional aspects, considering agency aspects related to interests, objectives and potential goal conflicts enables us to assess the outcome of business activities with respect to the SDGs, and to generate policy recommendations for business as well as other actors in the field. In particular, the framework can inform the analysis and discussion of the assumptions, interests and potential conflicts between actors or actor constellations in the respective international human rights subfields, with respect to the normative goals of efficiency, equity and voice, or the broader societal goals of wealth, justice and democracy.

\subsection{The impact of MNEs on the SDGs: the moderating effect of BHR governance}

The idea of BHR governance moderating the relationship between MNEs and the SDGs can be further illustrated by using an established graphical model that describes the impact of MNE activities and FDI on emerging economies. The original model of Meyer (2004) focuses on the link between MNE activities and FDI to environmental, social, institutional and economic variables. Kolk (2016) and Kolk et al. (2017) adapt this model to analyse the impact of MNEs on sustainable development. While Kolk et al. (2017) distinguish between four sets of development 
goals related to people, planet, peace and prosperity, Kolk (2016) uses the categories "justice" and "dignity" instead of "peace". The different models argue that the SDG categories are affected directly by the activities of MNEs, and indirectly through international business activities' impact on local firms and other organisations. The analysis finds that MNEs "can have a clear impact on sustainable development, both through the negative social and environmental externalities and, as they are increasingly portrayed, as a provider of solutions" (Kolk et al., 2017).

We adapt the model of Kolk et al. (2017) to illustrate the moderating role of BHR governance as an institutional filter to the relationship between MNE activities and outcome variables (Figure 3). Like Kolk et al., the model highlights the linkages between MNE activities and potential outcomes with respect to the sustainable development-related people, planet, peace and prosperity categorisation. Our adaptation and extension add BHR governance as an institutional process. In line with traditional input-output models, business activities as an input factor are moderated (and catalysed) by the institutional processes prescribed by the BHR governance system during which they become social and economic outcomes affecting planet, people, prosperity and peace.

We argue that these behaviour-outcome relationships are moderated by institutional governance systems that regulate (govern) the formal and informal relationships and interactions between business organisations (usually as human rights dutybearers) and rights-holders in order to pursue their objectives. A combination of the UNGPs and the BHR governance approach may be such a moderating institutional setting. This leads us to a proposition and a testable hypothesis:

Proposition 1: The business and human rights governance system moderates the relationship between business behaviour and sustainable development outcomes.

Hypothesis 2: Companies' exposure to UNGPs-based business and human rights governance is positively related to their contribution to the achievement of the SDGs.

How can the idea of using BHR governance as moderator in the relationship between business activities and the achievement of the SDGs be used in practice by corporate and public policy actors? Drawing on our earlier distinction between the design, implementation and evaluation stages, the following section uses the topical themes at the interface between IB and business and human rights identified by Wettstein et al. (2019) to illustrate the potential applications of our proposed approach.

From a corporate perspective, MNEs operating in different countries and institutional settings have to find ways to balance different pressures of global standardisation and local responsiveness (Ghoshal and Bartlett, 1989), which can be particularly challenging with respect to CSR and business ethics-related issues, and that 
Figure 3. Business and human rights governance moderates the link between MNEs and SDGs

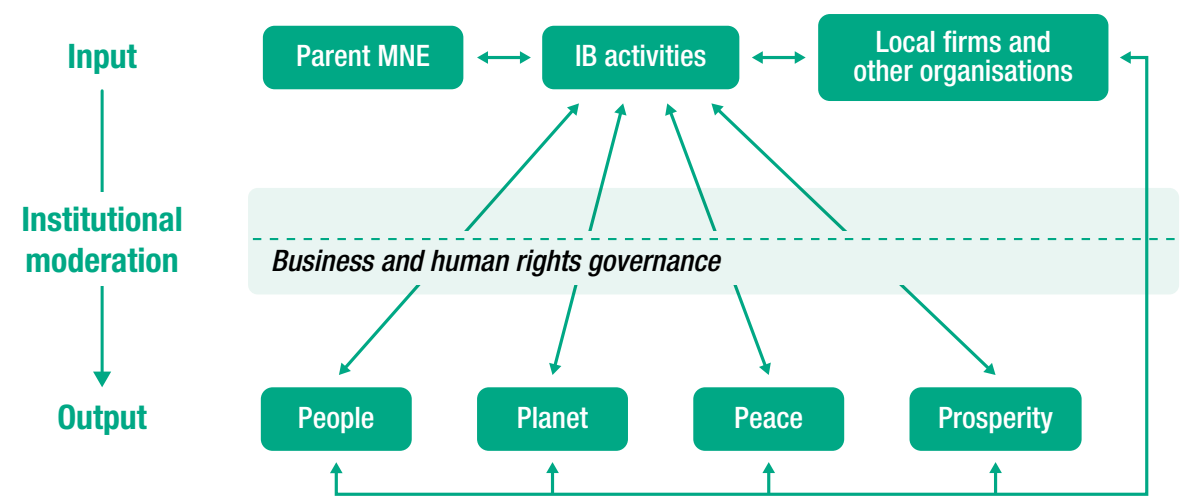

Source: Zagelmeyer and Sinkovics, adapted from Kolk (2016); Kolk et al. (2017); Meyer (2004).

ultimately affect a corporation's contribution (or lack thereof) to the achievement of the SDGs. The issues involved and the potential of the BHR governance approach can be illustrated in three areas: institutional voids, MNE headquarter-subsidiary relations and global value chains governance.

One recurring theme for corporations is the variation in formal and informal institutions across countries. While this issue has been extensively addressed by comparative institutional analysis, discussion of the role of business in the SDGs inevitably leads to the phenomenon of "institutional voids" and "weak" institutions, especially with respect to corruption, government effectiveness, the rule of law and human rights protection. For corporate-level IB strategy, such situations pose a challenge for the development of market and non-market strategies with implications for social responsibility and accountability. As the guidance of "strong" institutions is missing, companies are expected to fill the institutional voids and governance gaps themselves through private governance. In the face of weak institutions and incentives for potential institutional arbitrage through the opportunistic exploitation of the institutional settings, companies may face tradeoffs with respect to policies and behaviour consistent with profit maximisation on the one hand and socially responsible behaviour on the other. In this situation, the BHR governance approach, based on the UNGPs, may provide the principles and analytical tools to fill the institutional void and governance gaps. In the respective decision-making processes, the UNGPs may be used as principles to filter and thus identify and design human rights-compatible policies and practices that, on the one hand, avoid human rights-related harm, and, on the other, contribute to the achievement of the SDGs. The principles and tools provided by the governance approach can then be used to design and structure the implementation process, 
and to guide the analytical processes at the evaluation stage. From the perspective of public policymakers, involved, for example, in country-level policies addressing forms of modern slavery or the implementation of national action plans on sustainable development, the BHR governance approach may be used to assess corporate activities, by using the UNGPs as a reference point and using the available conceptual and analytical tools in the evaluation process.

While the previous section addresses the issue of institutional voids and governance gaps at a general level, international business has a long tradition of analysing the relationships between the parent organisation/headquarter and subsidiaries. More recently, attention has shifted from the internal organisation of MNEs to the external environment of MNEs, i.e. the relationships between MNEs and their cooperation partners in business ecosystems and the role of MNEs in global value chains. Issues related to governance, control, legitimacy and accountability occur with respect to internal and external organisational configurations of international business activities. Again, BHR governance can act as moderator or filter with respect to the design, implementation and evaluation of corporate policies and their potential impact on the SDGs. This can be very helpful with respect to diligence activities, alliance management, and non-financial reporting. The UNGPS can provide principles and a reference point, while the BHR governance approach can provide the conceptual and analytical framework for (i) assessing strategic choice options in decision-making processes; and (ii) evaluating policies and practices with respect to human rights compatibility and thus their contribution to the SDGs. This equally applies to decision-making and evaluation processes linked to corporate actors and public policymakers.

\section{Conclusion, policy relevance, and research agenda}

The SDGs represent a milestone in international development policy. In addition to specifying 17 goals and 169 targets, the SDGs ascribe a significant role to business organisations in sustainable development, a challenge many MNEs have accepted. This paper analysed and discussed the link between international business activities and the achievement of the SDGs, and argued that BHR governance can play a potentially important role in moderating the relationship between MNEs and the SDGs. This final section outlines areas for future research and offers some concluding thoughts about the potential implications for public policy.

As far as future research is concerned, BHR governance is connected to the developing research agendas of international business, human rights, and sustainable development. The proposed approach connects different strands in the emerging debates on the links between international business and human rights (Giuliani, 2018; Wettstein et al., 2019), international business and sustainable 
development (Kolk et al., 2017; Kolk et al., 2018; van Tulder, 2018; van Zanten and van Tulder, 2018), and human rights in sustainable development (Pogge and Sengupta, 2016; Winkler and Williams, 2017). Furthermore, it relates to the academic and public policy debates on the regulation of MNEs in global governance (Banerjee, 2014; Human Rights Council, 2015; Ruggie, 2018) as well as the link between international business and global justice (Arnold, 2013; Risse, 2012; Wettstein, 2009). Against this background, we briefly outline three suggestions for potentially fruitful future research.

i. BHR as a moderator between IB activities and the SDGs: This involves the empirical analysis and evaluation of the contribution of MNEs to the achievement of the SDGs, which could test the proposed moderating role in the link between business and the SDGs. Appreciating the complexity of measuring and assessing the corporate impact on the SDGs, the BHR governance approach provides a holistic view of corporate impact, involving a set of universally applicable principles and reference points (human rights) and the respective conceptual and analytical tools for assessing the impact of actors, strategies and governance structures on efficiency, equity and voice. By using human rights as reference point, corporate policies and practices can be assessed in terms of avoiding human rights-related harm and contributing to the realisation of human rights, and thus the achievement of the SDGs.

ii. Actor heterogeneity and institutional complexity: Another potential strand for future research could be to address the issues of actor heterogeneity and institutional complexity. These issues include exploration and analyses with respect to managing international business in the face of institutional voids and cross-country variation in institutional settings, varying combinations of country of origin and host countries with divergent human rights records, and the link between business and human rights-related activities and organisational configurations at different levels (e.g. headquarters versus subsidiaries) and characteristics (e.g. emerging market and/or state-owned enterprises). Distinguishing between these different types of international business activities, such as trade, alliances, FDI, or nonmarket strategies may also yield interesting insights.

iii. Research on economic and social upgrading in regional and global value chains: Following the work of Gereffi and Lee (2016) and Sinkovics, Hoque and Sinkovics (2016), future work is encouraged to explore and analyse the implications of BHR governance for the strategic interaction between MNEs (e.g. MNEs from developed countries interacting with emerging market MNEs in different markets and geographical locations) as well as for economic and social development. Such endeavours would offer valuable foundational information for analysing regulatory requirements and capabilities, and the appropriate level, breadth and 
depth of public policy regulation to create a level playing field for competitors. An extension of this research could additionally differentiate between industries (e.g. resource extraction, tourism, apparel, pharmaceutical) and sectors (e.g. public versus private, or formal versus informal).

Beyond informing future research, the proposed approach is also relevant for public policymaking. The BHR governance system governs the relationships and interaction between business organisations as human rights duty-bearers and rights-holders as they pursue their interests, which relate to the three objectives of efficiency, equity and voice. The societal need to balance these three objectives can be supported through a BHR governance system that includes specific configurations of governance structures, which provide the formal and informal institutional rules for the relationships between the different actors in the business and human rights field.

The BHR governance approach provides a genuine structure for exploring, analysing and discussing the link between business and the SDGs, highlighting aspects in relation to actors, their relationships, governance and outcomes. With respect to the actors involved, there is a need to identify all relevant actors, their underlying interest and goals with respect to the relationships between human rights dutybearers and rights-holders, as well as the strategic options, and determinants for respective choices.

The essential elements of the approach are the relationships between different actors that potentially affect the dyadic relationship between human rights dutybearers and rights-holders. Is every actor considered legitimate by the other actors? What is the balance of power between the different actors? To what extent are their interests, goals and strategies conflicting? In case of conflicting interests, goals and strategies, the question emerges how the institutionalisation of a BHR governance system, for example using the UNGPs as a reference point, can be designed in order to optimise the contribution of business to sustainable development. Which governance mechanisms and governance systems are in place to govern the relationships between human rights duty-bearers and rights-holders? To what extent do the respective governance systems contribute to certain outcomes related to equity (or justice), voice (or legitimacy) and efficiency (or wealth)? To what extent do outcome combinations contribute to stability and peace? To what extent do the outcomes contribute to the achievement of the SDGs?

Finding an optimal balance between equity, voice and efficiency can contribute to the achievement of the SDGs. Considering the 4P categorisation, efficiency in the allocation of scarce resources contributes to achieving prosperity. By ensuring the internalisation of external effects, efficiency, defined as macro-level efficiency, will also contribute to protecting the planet. Ensuring equitable and fair treatment 
to provide for effective voice, irrespective of power positions, and drawing on the efficient use of resources will contribute to achieving the SDGs in a peopleoriented way.

In the sustainable development context, the BHR governance system can be used, on the one hand, to avoid human rights-related harm by establishing a safety net of minimum human rights-related standards, for example by outlawing slave labour. On the other hand, the BHR governance system can be used to negotiate and agree on substantive and procedural terms and conditions on human rights-related issues, such as environmental and product quality standards that can contribute to the realisation of human rights beyond the absolute minimum standards. Using human rights as a reference point for companies and public policymakers can help identify business policies and practices that avoid human rights-related harm and/ or support the realisation of human rights, and thus support the achievement of the SDGs and the underlying sustainable development policy objectives. 


\section{References}

Alston, P. (2005). Ships passing in the night: The current state of the human rights and development debate seen through the lens of the millennium development goals. Human Rights Quarterly, 27(3), 755-829.

Arnold, D. G. (2013). Global justice and international business. Business Ethics Quarterly, 23(1), 125-143.

Backer, L. C. (2012). From institutional misalignments to socially sustainable governance: The guiding principles for the implementation of the united nations protect, respect and remedy and the construction of inter-systemic global governance. Global Business \& Development Law Journal, 25, 72-171.

Banerjee, S. B. (2014). A critical perspective on corporate social responsibility - towards a global governance framework. Critical Perspectives On International Business, 10(1/2), 84-95.

Banon Gomis, A., Guillen Parra, M., Hoffman, W. M., and McNulty, R. E. (2011). Rethinking the concept of sustainability. Business and Society Review, 116(2), 171-191.

Ghoshal, S., and Bartlett, C. A. (1989). Managing across borders - the transnational solution. Boston: Harvard Business School Press.

BLIHR. (2010). The millennium development goals and human rights: Companies taking a rights-aware approach to development. Business Leaders Initiative on Human Rights.

Budd, J. W. (2004). Employment with a human face: Balancing efficiency, equity and voice. Ithaca: Cornell University Press.

Bush, S. R., Oosterveer, P., Bailey, M., and Mol, A. P. J. (2015). Sustainability governance of chains and networks: A review and future outlook. Journal of Cleaner Production, 107, 8-19.

Carley, M., and Christie, I. (1992). Managing sustainable development. London: Earthscan Publications.

Commission of the European Communities. (2002). Corporate social responsibility: A business contribution to sustainable development. Communication from the Commission, COM(2002) 347 final. Brussels: Commission of the European Communities.

Doh, J., Rodrigues, S., Saka-Helmhout, A., and Makhija, M. (2017). International business responses to institutional voids. Journal of International Business Studies, 48(3), 293-307.

Dunning, J. H. (1981). Explaining the international direct investment position of countries: Towards a dynamic or developmental approach. Weltwirtschaftliches Archiv, 119, 30-64.

Dunning, J. H., and Narula, R. (1996). The investment development path revisited: Some emerging issues. In J. H. Dunning, and R. Narula (Eds.), Foreign direct investment and governments: Catalysts for economic restructuring: 1-40. London: Routledge.

Fukuda-Parr, S., and Greenstein, J. (2013). Monitoring MDGs - a human rights critique and alternative. In M. Langford, A. Sumner, and A. E. Yamin (Eds.), The millennium development goals and human rights: Past, present and future: 439-460. Cambridge: Cambridge University Press. 
Gereffi, G., and Lee, J. (2016). Economic and social upgrading in global value chains and industrial clusters: Why governance matters. Journal of Business Ethics, 133(1), 25-38.

Ghoshal, S., and Bartlett, C. A. Managing across borders - the transnational solution. Boston: Harvard Business School Press.

Giuliani, E. (2018). Why multinational enterprises may be causing more inequality than we think. Multinational Business Review, 27(3), 221-225.

GRI, UNGC, and WBCSD. (2015). SDG compass - the guide for business action on the SDGs.

Gready, P., and Ensor, J. (2016). What do human rights mean in development? In J. Grugel, and D. Hammett (Eds.), The Palgrave Handbook of International Development: 453-470. London: Palgrave Macmillan.

Harriss, J. (2014). Development theories. In B. Currie-Alder, R. Kanbur, D. M. Malone, and M. Rohinton (Eds.), International development: 35-49. Oxford: Oxford University Press.

Hart, S. L. (1997). Beyond greening: Strategies for a sustainable world. Harvard Business Review, 75(1), 66-76.

Human Rights Council. (2015). Summary of discussions of the forum on business and human rights. Human Rights Council Forum on Business and Human Rights Third session 1-3 December 2014. Geneva: Human Rights Council.

ILO. (2017). Tripartite declaration of principles concerning multinational enterprises and social policy. Geneva: International Labour Organization.

Khanna, and Palepu. (1997). Why focused strategies may be wrong for emerging markets. Harvard Business Review, 75, 41-51.

Kolk, A. (2016). The social responsibility of international business: From ethics and the environment to CSR and sustainable development. Journal of World Business, 51(1), 23-34.

Kolk, A., Kourula, A., and Pisano, N. (2017). Multinational enterprises and the sustainable development goals: What do we know and how to proceed? Transnational Corporations, 24(3), 9-32.

Kolk, A., Rivera-Santos, M., and Rufín, C. (2018). Multinationals, international business, and poverty: A cross-disciplinary research overview and conceptual framework. Journal of International Business Policy, 1(1-2), 92-115.

Kolk, A., and van Tulder, R. (2010). International business, corporate social responsibility and sustainable development. International Business Review, 19(2), 119-125.

Kuruvilla, S., Singh, A., Bustreo, F., Friedman, E., Hunt, P., and Luchesi, T. (2012). The millennium development goals and human rights: Realizing shared commitments. Human Rights Quarterly, 12, 141-177.

Langford, Malcolm, Sumner, Andy, Yamin, E., and Alicia. (2013). Introduction: Situating the debate. In M. Langford, A. Sumner, and A. E. Yamin (Eds.), The millennium development goals and human rights: Past, present and future: 1-34. Cambridge: Cambridge University Press. 
Langford, M. (2016). Lost in transformation? The politics of the sustainable development goals. Ethics \& International Affairs, 30(2), 167-176.

Mares, R. (2015). Global corporate social responsibility, human rights and law: An interactive regulatory perspective on the voluntary-mandatory dichotomy. Transnational Legal Theory, 1(2), 221-285.

Mclnerney-Lankford, S., and Sano, H.-O. (2010). Human rights indicators in development. Washington: The World Bank.

Meyer, K. E. (2004). Perspectives on multinational enterprises in emerging economies. Journal of International Business Studies, 35(4), 259-276.

Monkelbaan, J. (2018). Governance for the sustainable development goals. New York NY: Springer Berlin Heidelberg.

Moran, M., and Stone, D. (2016). The new philanthropy: Private power in international development policy? In J. Grugel, and D. Hammett (Eds.), The Palgrave Handbook of International Development: 297-313. London: Palgrave Macmillan.

OECD. (2011). OECD guidelines for multinational enterprises. Paris: OECD Publishing.

OECD. (2016). Better business for 2030: Putting the SDGs at the core. OECD Policy Note. Paris: OECD Emerging Markets Network.

OECD. (2018a). OECD due diligence guidance for responsible business conduct. Paris: OECD.

OECD. (2018b). Policy note on sustainability - better business for 2030: Putting the SDGs is at the core Paris: OECD.

OHCHR. (2008). Claiming the millennium development goals: A human rights approach. New York and Geneva: UN.

OHCHR. (2010). Human rights and the millennium development goals in practice: A review of country strategies and reporting. New York and Geneva: UN.

OHCHR. (2011). Guiding principles on business and human rights - implementing the United Nations 'protect, respect and remedy' framework. Geneva: Office of the UN High Commissioner for Human Rights.

OHCHR. (2012). The corporate responsibility to respect human rights: An interpretive guide. Geneva: Office of the UN High Commissioner for Human Rights.

OHCHR. (2014). Frequently asked questions about the Guiding Principles on Business and Human Rights. Geneva: Office of the UN High Commissioner for Human Rights.

Oxfam. (2017). Raising the bar - rethinking the role of business in the sustainable development goals. Oxfam Discussion Papers. Oxford: Oxfam.

Oxfam. (2018). Walking the talk - assessing companies' progress from SDG rhetoric to action. Oxfam Discussion Papers. Oxford: Oxfam.

Pogge, T., and Sengupta, M. (2016). Assessing the sustainable development goals from a human rights perspective. Journal of International and Comparative Social Policy, 32(2), 83-97. 
Porter, M., and Kramer, M. (2006). The link between competitive advantage and corporate social responsibility. Harvard Business Review, 84, 78-92.

Posner, M. (2015). Shared responsibility: A new paradigm for supply chains. Global Agenda Council, November 2015.

Redclift, M. R., and Springett, D. (2015). Routledge international handbook of sustainable development. London; New York NY: Routledge Taylor \& Francis Group.

Risse, M. (2012). On global justice. Princeton: Princeton University Press.

Ruggie, J. G. (2013). Just business: Multinational corporations and human rights. New York: W.W. Norton.

Ruggie, J. G. (2014). Global governance and new governance theory: Lessons from business and human rights. Global Governance, 20, 5-17.

Ruggie, J. G. (2018). Multinationals as global institution: Power, authority and relative autonomy. Regulation \& Governance, 12(3), 317-333.

Sano, H. O. (2000). Development and human rights: The necessary, but partial integration of human rights and development. Human Rights Quarterly, 22(3), 734-752.

Schmidt-Traub, G. (2009). The millennium development goals and human rights-based approaches: Moving towards a shared approach. The International Journal of Human Rights, 13(1), 72-85.

Sen, A. (2003). Development as a capability expansion. In S. Fukuda-Parr (Ed.), Readings in human development: 41-58. Oxford: Oxford University Press.

Sen, A. (2004). Elements of a theory of human rights. Philosophy \& Public Affairs, 32(4), 315-356.

Sen, A. (2005). Human rights and capabilities. Journal of Human Development, 6(2), 151166.

Shift. (2016). Business, human rights and the sustainable development goals - forging a coherent vision and strategy London: Business \& Sustainable Development Commission.

Shift, and WBCSD. (2018). The human rights opportunity - 15 real-life cases of how businesses contributing to the sustainable development goals by putting people first. New York: Shift Project Limited.

Sinkovics, N., Hoque, S. F., and Sinkovics, R. R. (2016). Rana plaza collapse aftermath: Are CSR compliance and auditing pressures effective? Accounting, Auditing \& Accountability Journal, 29(4), 617-649.

Sinkovics, N., Sinkovics, R. R., Hoque, S. F., and Czaban, L. (2015). A reconceptualisation of social value creation as social constraint alleviation. Critical Perspectives on International Business, 11(3/4), 340-363.

The Danish Institute for Human Rights. (2019). Responsible business conduct as a cornerstone of the 2030 agenda - a look at the implications. Copenhagen: The Danish Institute for Human Rights. 
UN. (2000). United Nations Millennium Declaration. Resolution adopted by the General Assembly on 25 September 2015 (A/RES/ 55/2). New York: United Nations.

UN. (2015a). Transforming our world: The 2030 agenda for sustainable development. A/RES/70/1. Geneva: United Nations.

UN. (2015b). Transforming our world: The 2030 agenda for sustainable development. Resolution adopted by the General Assembly on 25 September 2015 (A/RES/ 70/1). New York: United Nations.

UN Commission on Human Rights. (2003). Draft Norms on the Responsibilities of Transnational Corporations and Other Business Enterprises with Regard to Human Rights. Economic and Social Council. E/CN.4/Sub.2/2003/12. 30 May 2003. New York: United Nations.

UNDP. Human rights and the millennium development goals - making the link. Oslo: United Nations Development Programme Oslo Governance Centre.

UNDP. (2013). Mainstreaming human rights in development. New York: United Nations Development Programme.

van Tulder, R. (2018). Business \& the sustainable development goals - a framework for effective corporate involvement. Rotterdam: Rotterdam School of Management, Erasmus University.

van Tulder, R., Verbeke, A., and Strange, R. (2014). Taking stock of complexity: In search of new pathways to sustainable development. Progress in International Business Research, 8, 1-20.

van Zanten, J. A., and van Tulder, R. (2018). Multinational enterprises and the sustainable development goals: An institutional approach to corporate engagement. Journal of International Business Policy, 1(3), 208-233.

Wagner, L.-J. (2017). How does the 2030 agenda relate to human rights?, Development in Brief. Berlin: KfW Development Research.

Weissbrodt, D. (2005). Business and human rights. University of Cincinnati Law Review, 74, 55-73.

Wettstein, F. (2009). Multinational corporations and global justice. Stanford Stanford Business Books.

Wettstein, F., Giuliani, E., Santangelo, G. D., and Stahl, G. K. (2019). International business and human rights: A research agenda. Journal of World Business, 54(1), 54-65.

Wettstein, F., and Waddock, S. (2005). Voluntary or mandatory: That is (not) the question - linking corporate citizenship to human rights obligations for business. Zeitschrift fuer Wirtschafts- und Unternehmensethik, 6(3), 304-320.

Williams, O. F. (2014). Corporate social responsibility: The role of business in sustainable development. London; New York: Routledge Taylor \& Francis Group.

Williamson, O. E. (1996). The mechanisms of governance. Oxford: Oxford University Press.

Winkler, I. T., and Williams, C. (2017). The sustainable development goals and human rights: A critical early review. International Journal of Human Rights, 21(8), 1023-1028. 
Witte, C., and Dilyard, J. (2017). Guest editors' introduction to the special issue: The contribution of multinational enterprises to the sustainable development goals. Transnational Corporations, 24(3), 1-8.

World Commission On Environment and Development. (1987). Our common future Oxford: Oxford University Press.

World Economic Forum. (2014). White paper on business sustainability: What it is and why it matters. Geneva: World Economic Forum, Global Agenda Councils. 10 September.

Zagelmeyer, S. (2020). MNEs and human rights: From responsibilities to rights to governance. Critical Perspectives on International Business, 1/2, (Advance online publication. https:// doi.org/10.1108/cpoib-07-2018-0063). 